\title{
Financial Performance and Stock Price: Another Review on Banks Listed in Indonesia Stock Exchange
}

\author{
Erlyta Agustine Noviyanti \\ Sanata Dharma University \\ erlyta.agustine@gmail.com \\ Caecilia Wahyu E. Rahayu \\ Sanata Dharma University \\ caecilia50@gmail.com \\ Christina Heti Tri Rahmawati \\ Sanata Dharma University \\ christinaheti.nugroho@yahoo.co.id
}

\begin{abstract}
Financial performance is an important factor to attract investors in buying stocks. This study aims to determine the influence of financial performance measured by Non-Performing Loan Ratio (NPL), Loan to Deposit Ratio (LDR), Capital Adequacy Ratio (CAR), Debt to Equity Ratio (DER), Return on Assets (ROA), and Net Profit Margin (NPM) on price of stocks of banks listed in the Indonesia Stock Exchange (IDX) during 2014-2018. Of 43 banks, there were only 31 banks fit the criteria under purposive sampling technique. The data used in this study are secondary data obtained from the official website of Indonesia Stock Exchange (www.idx.co.id). Multiple linear regression analysis was applied for analyzing the data that were tested for classic assumptions. The results showed that simultaneously NPL, LDR, CAR, DER, ROA and NPM had significant influence on stock prices. Partially, the result showed that only ROA and NPM had a significant influence on stock prices. Banks must then focus mainly on ROA and NPM in attracting investors.
\end{abstract}

Keywords: non-performing loan ratio (NPL), loan to deposit ratio (LDR), capital adequacy ratio (CAR), debt to equity ratio (DER), return on assets (ROA), net profit margin (NPM), stock price.

\section{INTRODUCTION}

Issue of performance of banks is considerably important since banking industry is a significant contributor of the economic development of a country (Murerwa, 2015). Banks with better performance have higher ability to resist any negative shocks coming from the external 
environment and thus are able to contribute to the sustainability of a country's financial system. This lies under the reason that the industry is a major source of finance to the economy. Banks, especially commercial banks, play a vital role in channeling funds from depositors to investors.

Ongore and Kusa (2013) noted that for sustaining this intermediation function, banks need to be profitable since they must generate necessary income for being able to cover operational costs incurred from their works. Profit is also the indication that the shareholders can get their dividends from their investment (Murerwa, 2015). This condition in turn can encourage the shareholders to invest more in the bank, which lead to steady flow of investment fund for the bank to sustain its operation. Considering to this, financial performance of banks has gained great attention of researchers and investors.

Financial performance can thus be vital information for making investment decision since it reflects health condition and prospect of the company in the future. Investors can scrutinize the bank' report on their financial performance before deciding to put or not to put their money in the bank (Karim \& Alam, 2013). Assessment on banks' financial performance can be done using financial ratios (Murerwa, 2015; Kasmir, 2014; Karim \& Alam, 2013) such as liquidity ratio, solvability ratio, and profitability ratio. These ratios indicate ability of the bank to perform respectively short term obligations, the extent of its activities that are financed using loans, and profit generating. Referring to Karim and Alam (2013), ratio analysis is simply a postmortem analysis of past financial data and thus additional effort must be made to understand the effect of different ratio on profitability of the bank by for example conducting correlation analysis and regression analysis.

Even though ratio analysis can help in identifying and highlighting the areas of poor and satisfactory performance of a bank and use the results for decision making purposes (Karim \& 
Alam, 2013), the investor may be reluctant to invest in a bank due to the price of the stock. Price of a stock usually changes along the time and changes in stock price create uncertainty. Stock price is one of the indicators of management success (Karamoy \& Tulung, 2020). If the stock price increases, the investors or potential investors think that the company is successful in managing the business and this will increase their trust which in turn attract more investors to invest in the company. Analysis on price stock is thus a basic step that must be conducted by investors before they really invest their money, otherwise they may be in the adverse condition. Karamoy and Tulung (2020) also stressed that stock price can be used to predict the company's prospect. Analyzing fundamental factors available in the financial statement and predicting the prospect from stock price are to understand company's performance that can affect its stock price. In other words, there is relationship between financial performance and stock price. Good financial performance measured using financial ratios and increase stock price since it increases trust of investors.

The research aims to identify influence of financial performance on stock price of banks listed in the Indonesia Stock Exchange (IDX). Referring to previous studies, there are variety measures that can be used to assess bank financial performance (Kasmir, 2014; Karim \& Alam, 2013; Ongore \& Kusa, 2013). The research relies on three basic ratios according to Kasmir (2014): liquidity ratio indicating ability of the bank to perform its short term liabilities, solvability ratio referring to the extent of the banks operational funded from liability, and profitability ratio that represents capability of the bank to generate profit. Two indicators are selected for each measure. Non-performing loan ratio (NPL) and loan to deposit ratio (LDR) are the indicators for liquidity ratio; capital adequacy ratio (CAR) and debt to equity ratio (DER) are those for solvability ratio; and return on assets (ROA) and net profit margin (NPM) are to measure profitability ratio. The research is more specifically to understand whether different ratio influences stock price in positive 
or negative direction. This is important for predicting the prospect of the bank according to the fluctuation in stock price that depends on the ratio. Partial and simultaneous influence also become the focus of the research in order to understand which ratios that significantly affect the stock price. The information can benefit investors or potential ones in making investment decision.

\section{LITERATURE REVIEW}

\section{Financial Performance of Banks}

Malayu (2008) defined commercial bank is a financial institution, money creator, fund collector and credit lender, executor in payment traffic, monetary stabilizer, and economic growth dynamisor. This definition shows vital role of banks in economic growth of countries since they contribute in the efficient allocation of resources of countries by mobilizing resources for productive activities (Ongore \& Kusa, 2013). They transfer funds from those who don't use them for productive activity to those who have productive one. According Karim \& Alam (2013), this intermediation function is essential role of a bank. Therefore, banks performance has gained attention from many researchers because their collapse or bankruptcy can have contagion effect on the economy. Banking crisis can entail financial crisis, which possibly then leads to economic crisis.

Performance of a company is indicated by financial condition. Using financial analysis tools, good and bad of the financial condition reflecting work performance in a particular period can be revealed. Financial condition of a company at a particular time or period is reflected in its financial statements (Kasmir, 2017). Financial statements are basically an accounting process used as the media of communication between financial data or activities of a company with the company's stakeholders (Munawir, 2012). They usually include profit and loss, financial position, 
equity changes, cash flow, and notes of the financial statements and indicate how resources can be used optimally in dealing with changes in the environment. Analyzing them to know and understand the company's performance better and precisely means that we dissect a financial statement into its elements and study each of them (Hery, 2015).

Ratio analysis is one method for analyzing and monitoring company's performance. It involves methods of calculating and interpreting financial ratios which particularly based on the company's income statement and balance sheet (Karim \& Alam, 2013). It helps identifying the areas that needs to be improved or maintained and also highlighting company's strengths and weaknesses. This information is essential for directing efforts for better performance. Bank's financial statements are thus important to be analyzed.

Scholars have come up with variety indicators to measure bank's financial performance such as interest margin, return on assets (ROA), capital adequacy, asset-liability management, net interest income (NIM), return on equity (ROE), asset management ratio, and so on (Karamoy \& Tulung, 2020; Murerwa, 2015; Karim \& Alam, 2013). Considering many indicators that can be used to measure performance of banks, Karim and Alam (2013:68) suggested that "a comprehensive performance analysis should go beyond traditional measure and should employ more forward-looking proxies while taking into account risk and profitability." The major ratios for measuring profitability of banks are ROA, ROE, and NIM (Ongore \& Kusa, 2013).

Bank performance is influenced by external and internal factors (Ongore \& Kusa, 2013). The external factors are macroeconomic ones such as inflation, interest rate, economic growth, policy stability, GDP. Meanwhile, the internal factors or bank specific factors are within the scope of the bank to manipulate them and thus are specific to each bank such as bank size, capital management efficiency, management quality, interest rate policy, risk management capacity, 
ownership, etc. CAMEL framework is then used by many to proxy the bank specific factors (Dang, 2011). It stands for capital adequacy, asset quality, management efficiency, earning ability, and liquidity.

Capital adequacy influences the level of bank profitability. It can be measured by different variables such as log of total assets (LTA), loan loss provisions to total loans, loans to assets, tax to operating profit before tax, overhead expenses to total assets, non-interest income to total assets, total revenue to number of employees and shareholders' equity to total assets (Murerwa, 2015). Among others, capital adequacy ratio (CAR) is the most common indicator of capital adequacy. It indicates the internal strength of the bank to endure losses in the case of crisis. Income of a bank comes predominantly from loans. They are the major asset from which bank income is generated. However, delinquent loans create the highest risks faced by a bank and thus non performing loans (NPL) becomes the best proxy for measuring asset quality of a bank.

Management efficiency shows capability of the management to use its resources efficiently. It is also a measure of bank profitability. In terms of this dimension, management efficiency can be measured quantitatively by applying financial ratios. The ratios are operating profit to income ratio, expense to asset ratio.

Liquidity refers the ability of the bank to fulfill its obligations in particularly the obligations to depositors. A bank with adequate level of liquidity can generate profitability. The most common measure of liquidity are customer deposit to total asset, total loan to deposits ratio (LDR), cash to deposit ratio (Ongore \& Kusa, 2013).

\section{Financial Performance and Stock Price}

1. Influence of non-performing loan (NPL) on stock price 
NPL or credit risk points to risks associating with losses possibility due to delinquent loans (Kasmir, 2014). Higher NPL indicates higher number of non-perform loans that in turn may lead the bank into worsen condition since non perform loans can reduce the bank's capital. On the other side, lower NPL will lower the problem and this influence investors' decision to buy the stock of the bank and thus price of the stock will increase. As Martanorika (2018) found, NPL influences negatively stock price. The relevant hypothesis for this is

H1: Non performing loan influences price of stocks listed in IDX negatively.

2. Influence of loan to deposit ratio (LDR) on stock price

LDR points to ability of the bank to pay depositors from credits as the source of liquidity. Higher LDR indicates lower liquidity capability of the bank. This means risk to invest in the bank is higher and thus investors have no interest to invest. Consequently, price of the stock declines. The opposite happens if LDR is lower. In line with the result of Martanorika (2018), the hypothesis that is relevant to this is

H2: Loan to deposit ratio influences price of stocks listed in IDX negatively.

3. Influence of capital adequacy ratio (CAR) on stock price

$\mathrm{CAR}$ is a ratio indicating to what extent risky assets of the bank (such as credit, securities) are financed by the owner's equity rather than the external funds. It is the indicator of the capability of the bank to withstand the decline of the assets due to losses incurred from the risky assets. Higher CAR indicates better capability of the bank to manage its equity for generating profit. Higher CAR leverages trust of the investors to the bank that in turn increase demand on the bank's stock. Price of the stock is higher as the consequent. The research by Kartadinata (2018) and Martanorika (2018) is in line with the hypothesis generated from this. 
H3: Capital adequacy ratio influences price of stocks listed in IDX positively.

4. Influence of debt to equity ratio (DER) on stock price

DER is a ratio of total liability and equity. Ang (1997) stated higher DER shows higher liability against the equity. This indicates the bank is highly dependent on creditors and thus risk faced by the bank is also higher since higher liability can possibly mean lower capability of the bank to pay it. Investors will usually not buy stock with high DER (Ang, 1997) and price of the stock will be lower. The hypothesis formulated from this is relevant to the results of Takarini and Hendrarini (2018), Yulita and Rahayu (2019) which is as follows

H4: Debt to equity ratio influences price of stocks listed in IDX negatively.

5. Influence of return on assets (ROA) on stock price

ROA is a ratio representing capability of the equity invested in assets to generate profit. It indicates productivity of the bank. Higher ROA means higher profit and thus lower possibility of the bank be in the crisis. Higher profit is the indicator for the investors to have increase profitability and this can attract more investors to have the stock of the bank that will make price of the stock to increase. This is in line with the research of Wijayanto (2015), Paska (2017), Ahmad et al. (2018), and Amanah et al. (2014). The hypothesis is thus formulated as follow

H5: Return on assets influences price of stocks listed in IDX positively.

6. Influence of net profit margin (NPM) on stock price

NPM is direct indicator to know net profit generated by the bank. Higher NPM means higher efficiency on expenses and thus higher return on net profit (Ang, 1997). NPM that keeps increasing points out capability of the management in managing the bank to gain profit. Escalation of trust of the investors caused by better NPM increases demand on the stock and in 
turn the price of the stock also increase. Wijayanto (2015) and Takarini and Hendrarini (2011)

revealed positive relationship between NPM and stock price and thus the hypothesis is formulated as

H6: Net profit margin influences price of stocks listed in IDX positively.

Besides partial influence of each financial ratio on stock price, they possibly influence stock price simultaneously. Thus, the hypothesis relevant to this is formulated as follow

H7: NPL, LDR, CAR, DER, ROA, and NPM simultaneously influence price of stocks listed in IDX.

\section{METHODS}

This research is quantitative descriptive, which is intended to identify effect of independent variables on the dependent variable (Sugiyono, 2014). The independent variables are NonPerforming Loan (NPL), Loan to Deposit Ratio (LDR), Capital Adequacy Ratio (CAR), Debt to Equity Ratio (DER), Return on Assets (ROA), and Net Profit Margin (NPM). The dependent variable is stock price. The research was conducted on banks listed in the Indonesia Stock Exchange (IDX) in the period of 2014-2018. It is the period in which the most current data available during the time of the research.

All banks listed in IDX comprise of 43 companies and thus they become the population members. However, there were only 31 banks that fit the criteria determined using purposive sampling technique (Sugiyono, 2014). Only banks that fit the following criteria were selected as the sample: listed in IDX during 2014-2018, issue annual financial statements consistently each year, and have continuous stock price data (without intermittent) during the period of the research. The data needed to measure financial ratios and stock price were sourced from the banks' financial 
statements. They are thus quantitative and historical data and were gathered using documentary method (Sugiyono, 2014) from the official website of IDX www.idx.co.id.

Before analyzing the data, classical assumption tests were applied to know whether the regression model used for data analysis really shows significant relationship and representative (Ghozali, 2011). In more particularly, the model must fall under classical assumptions of regression, which cover normality test, multicollinearity test, autocorellation test, and heteroscedasticity test.

Multiple linear regression analysis was used to prove the influence of financial ratios on stock price (Sujarweni, 2015). F test and t test were applied to accept or to reject the hypotheses. Coefficient of determination (adjusted $\mathrm{R}$ square in this case) was used to know percentage of changes of dependent variable caused by independent variables Sujarweni (2015).

\section{RESULT AND DISCUSSION}

\section{Classical Assumption Test}

1. Normality test

Normality test is to test if residuals of the dependent and independent variables are distributed normally in the regression model. If significant value of Kolmogorov-Smirnov (KS) $>0.05$, the residual data are normally distributed and if sig. K-S $\leq 0.05$ the data are not distributed normally. The result of Kolmogorov-Smirnov (K-S) test is presented in table 1 . From table 1, Asymp. Sig (2-tailed) is 0.576 , which is bigger than 0.05 . This means that the data are distributed normally. 
Table 1. Normality Test

One-Sample Kolmogorov-Smirnov Test

\begin{tabular}{cccccc}
\hline $\begin{array}{c}\text { Unstandardized } \\
\text { Residual }\end{array}$ & $\mathbf{N}$ & $\begin{array}{c}\text { Kolmogorov- } \\
\text { Smirnov Z }\end{array}$ & $\begin{array}{c}\text { Asymp. Sig } \\
\text { (2-tailed) }\end{array}$ & $\begin{array}{c}\text { Sig. } \\
* \text { Critical }\end{array}$ & Information \\
\hline Model & 155 & 0.781 & 0.576 & 0.05 & Normal \\
\hline
\end{tabular}

Source: Processed data (2020)

2. Multicollinearity test

Multicolinearity test was intended to test if correlation between independent variables exist in the regression model. A good regression model should not consist correlation between its independent variables. To detect existence of multicollinearity in the regression model, tolerance value and Variance Inflation Factor (VIF) were applied. If tolerance value $>0.1$ and VIF $<10$, thus there is no multicollinearity and if tolerance value $\leq 0.1$ and VIF $>10$, multicollinearity between variables exists.

Based on the table of Output Coefficients in particularly on Collinearity Statistics, it is known that tolerance for NPL is $0.781, \mathrm{LDR}$ is 0.783 , CAR is 0.546 , DER is 0.514 , ROA is 0.799 and NPM is 0.684 , which each is bigger than 0.10 . Meanwhile the VIF for NPL is 1.280, LDR is 1.277, CAR is 1.832 , DER is 1.947 , ROA is 1.251 and NPM is 1.462 which each is less than 10.00. Based on the decision criteria, it is concluded that there was no multicollinearity in the regression model.

Table 2. Result of Multicollinearity Test

\begin{tabular}{cccccc}
\hline $\begin{array}{c}\text { Dependent } \\
\text { Variable }\end{array}$ & $\begin{array}{c}\text { Independent } \\
\text { Variable }\end{array}$ & Tolerance & $\begin{array}{c}\text { VIF } \\
\text { Value }\end{array}$ & $\begin{array}{c}\text { VIF. } \\
* \text { Critical }\end{array}$ & Information \\
\hline NPL & & 0,781 & 1,280 & 10 & $\begin{array}{c}\text { Multi-linearity does not } \\
\text { occur }\end{array}$ \\
LDR & Stock price & 0,783 & 1,277 & 10 & $\begin{array}{c}\text { Multi-linearity does not } \\
\text { occur }\end{array}$ \\
& & & & &
\end{tabular}




\begin{tabular}{|c|c|c|c|c|c|}
\hline $\begin{array}{l}\text { Dependent } \\
\text { Variable }\end{array}$ & $\begin{array}{c}\text { Independent } \\
\text { Variable }\end{array}$ & Tolerance & $\begin{array}{l}\text { VIF } \\
\text { Value }\end{array}$ & $\begin{array}{c}\text { VIF. } \\
* \text { Critical }\end{array}$ & Information \\
\hline CAR & & 0,546 & 1,832 & 10 & $\begin{array}{c}\text { Multi-linearity does not } \\
\text { occur }\end{array}$ \\
\hline DER & & 0,514 & 1,947 & 10 & $\begin{array}{c}\text { Multi-linearity does not } \\
\text { occur }\end{array}$ \\
\hline ROA & & 0,799 & 1,251 & 10 & $\begin{array}{c}\text { Multi-linearity does not } \\
\text { occur }\end{array}$ \\
\hline NPM & & 0,684 & 1,462 & 10 & $\begin{array}{c}\text { Multi-linearity does not } \\
\text { occur }\end{array}$ \\
\hline
\end{tabular}

Source: Processed data (2020)

3. Heteroscedasticity Test

Heteroscedasticity test was conducted to examine if there is inequality variance of residual in the regression model from one observation to another. A good regression model is the model that is homoscedasticity or no heteroscedasticity. A model does not experience heteroscedasticity disturbance if the scatterplot does not create particular pattern or concentrate in a node.

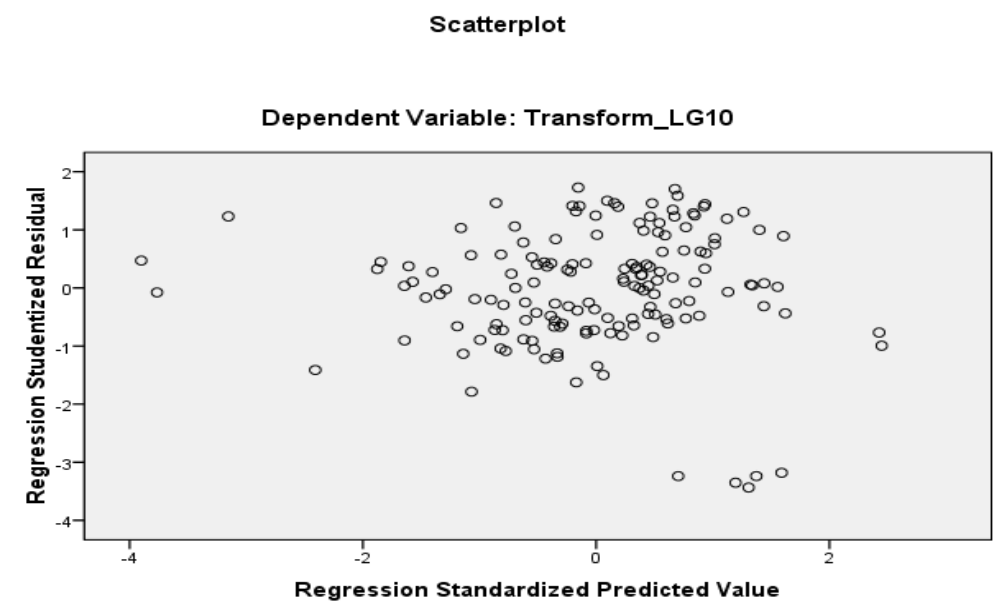

Figure 1. Heteroscedasticity Test

Source: Processed data (2020) 
Based on figure 1, it is known that the dots are scattered around 0 and not only pooled above or below 0 , and the distribution does not have a pattern. It can thus be concluded that there is no heteroscedasticity in the regression model.

4. Autocorrelation test

Autocorrelation was conducted to know relationship between data in a variable. The decision for existence of autocorrelation is based on the value of Durbin-Watson (DW). If the value of DW falls between upper bound (du) and (4-du), coefficient of autocorrelation is zero and thus no autocorrelation.

Table 3. Autocorrelation

\begin{tabular}{ccccc}
\hline \multirow{2}{*}{ Regression } & DW & \multicolumn{2}{c}{$\begin{array}{c}\text { DW Limit Free of } \\
\text { Autocorrelation }\end{array}$} & Information \\
\cline { 3 - 4 } & & $\begin{array}{c}\mathbf{d U} \\
(\text { minimum)* }\end{array}$ & $\begin{array}{c}\mathbf{4}-\mathbf{d U} \\
\text { (maximum) }\end{array}$ & \\
\hline Model & 1,862 & 1,8184 & 2,1816 & No \\
& & & & autocorrelation \\
\hline
\end{tabular}

Source: Processed data (2020)

From the table of Output Model Summary, it is known that Durbin-Watson (d) is 1.862. Table value of Durbin-Watson on $5 \%$ significance was determined using formula $(\mathrm{K} ; \mathrm{N})$. With 6 independent variables and 155 samples, thus $(\mathrm{K} ; \mathrm{N})=(6 ; 155)$. Based on the distribution of Durbin-Watson table, it can be found that dL is 1.6578 and dU is 1.8184 , Durbin-Watson (d) value of 1.862 is bigger than (dU) amounted 1.8184 and less than (4-dU) amounted 2,1816. Thus can be concluded that there is no evidence that autocorrelation exists.

Classical assumption tests result in the condition in which the data can be processed further as they can give best unbiased linear regression. 


\section{Multiple Linear Regression Analysis}

Based on the result of the regression analysis presented in table 4, the regression model can be formulated as follows:

$$
Y=814,724+140,006 X_{1}+3,827 X_{2}-17,050 X_{3}-79,040 X_{4}+245,232 X_{5}+34,475 X_{6}
$$

It can be seen that among the independent variables, only CAR and DER give negative effect on stock price, which higher CAR or DER reduces stock price and vice versa. On the other hand, stock price increases/declines according to the increase/decline of NPL, LDR, ROA, and NPM

Table 4. Results of the Multiple Linear Regression

\begin{tabular}{crrrr}
\hline \multirow{2}{*}{ Model } & \multicolumn{2}{c}{ Unstandardized Coefficient } & \multirow{2}{*}{ t } & \multirow{2}{*}{ Sig } \\
\cline { 2 - 3 } & \multicolumn{1}{c}{$\mathrm{B}$} & Std. Error & & \\
\hline Constant & 814.724 & 1300.027 & 0.627 & 0.532 \\
NPL $\left(\mathrm{X}_{1}\right)$ & 140.006 & 90.387 & 1.549 & 0.124 \\
LDR $\left(\mathrm{X}_{2}\right)$ & 3.827 & 9.578 & 0.400 & 0.690 \\
CAR $\left(\mathrm{X}_{3}\right)$ & -17.050 & 24.172 & -0.705 & 0.482 \\
DER $\left(\mathrm{X}_{4}\right)$ & -79.040 & 65.913 & -1.199 & 0.232 \\
ROA $\left(\mathrm{X}_{5}\right)$ & 245.232 & 92.358 & 2.655 & 0.009 \\
NPM $\left(\mathrm{X}_{6}\right)$ & 34.475 & 9.225 & 3.737 & 0.000 \\
\hline \multicolumn{2}{c}{ Source: Processed data $(2020)$} & & &
\end{tabular}

t test

The $t$ test on the influence of each financial ratio on stock price shows that probability (sig) value of NPL (0.124), LDR (0.690), CAR (0.482), and DER (0.232) are bigger than the threshold $\alpha$ of 0.05 . This shows that each variable does not influence significantly stock price. Only ROA and NPM that have probability (sig) value less than $\alpha 0.05$, which is respectively 0.009 and 0.000. In other words, only H5 and H6 are accepted. Thus, it can be stated that ROA and NPM partially affect positively and significantly stock price.

F test

Even though partially only ROA and NPM influence stock price significantly, F test shows that all variables (NPL, LDR, CAR, DER, ROA and NPM) simultaneously affect stock 
price significantly. The probability (sig) value of 0.000 which is lower than 0.05 indicates this (table 5).

Table 5. F Test Result

\begin{tabular}{llcc}
\hline & & F & Sig. \\
\hline \multirow{2}{*}{1} & Rogression & 7.091 & $.000^{\mathrm{a}}$ \\
& $\begin{array}{l}\text { Residual } \\
\text { Total }\end{array}$ & & \\
\hline
\end{tabular}

a. Dependent Variable: Stock Price (Y)

b. Predictors: (Constant), NPL (X1), LDR (X2), CAR (X3), DER (X4), ROA (X5), NPM (X6)

Source: Processed data (2020)

\section{Coefficient of determination}

The coefficient is to measure percentage of influence of independent variables toward the dependent variable. The analysis results in adjusted $\mathrm{R}$ square of 0.192 . This indicates that NPL, LDR, CAR, DER, ROA, and NPM give $19.2 \%$ contribution to the variation of stock price and the rest $(80.8 \%)$ is influenced by other variables excluded from this research, such as external factors of political issues, deposit, exchange rate, fluctuation of interest rate, inflation, regulations, and so on.

Table 6. Coefficient of Determination

\begin{tabular}{|c|c|c|c|c|}
\hline Model & $\mathrm{R}$ & R Square & $\begin{array}{c}\text { Adjusted R } \\
\text { Square }\end{array}$ & $\begin{array}{l}\text { Std. Error of the } \\
\text { Estimate }\end{array}$ \\
\hline 1 & $.473^{\mathrm{a}}$ & .223 & .192 & 1567.076 \\
\hline
\end{tabular}
(X6)

Source: primary data (2020)

\section{Discussion}

Previous studies show that the main factors influencing investors' decision is profitability. Since ROA and NPM are the indicator of profitability of banks, they thus significantly influence stock price. Higher profit indicated by higher ROA and NPM attract interest of investors to buy the stock that then increase the price of the stock. On the other side, NPL, LDR, CAR, and DER do not influence stock price since they are not he direct indicator 
of profitability. Regulations set by the central bank regarding to these ratios to monitor operational of banks in general help the investors to disregard them when making investment decision.

Similar to Martanorika's (2018), the research also results in NPL does not influence stock price. The possible reason for this to happen is the standard of NPL set by the central bank (Bank Indonesia) to assure commercial banks are in a vigor level. A bank is considered as vigorous if its NPL is $5 \%$ maximum. Bank Indonesia will monitor those with NPL lower than $5 \%$ to each the standard. Investors thus can make decision by disregarding credit quality reflected by NPL.

Previous studies show that the main factors influencing investors' decision is profitability. Ability of the bank to give credits and to get deposits are considerably not the indicator of ability of the bank to generate profit. Moreover, Bank Indonesia sets the upper level of LDR that must be met by banks amounted as $85 \%-110 \%$ (Bank Indonesia, 1998). Bank Indonesia will give penalty to banks that do not met the standard amounted $0.1 \%$ of the total deposits for each $1 \%$ lower of LDR. Also, as its role as the lender of the last resort Bank Indonesia will help banks experiencing difficulty in their liquidity. It can be stated that investors may disregard LDR in their decision on buying stock of banks.

Regulation in relation to CAR states that bank must meet minimum capital ratio amounted $8 \%$. This means that every bank must have extra fund to meet the minimum standard as well as to anticipate credit risks. Investors may not be interested in the amount of capital owned by the bank since it does not reflect quality of the bank. What is more important is the ability of the bank in distributing the capital for generating profit. Fordian (2017) also confirmed the same result in which CAR does not influence stock price. 
Investors usually do not choose stocks with high DER since high DER reflects high risk. However, if the bank shows it can manage its liabilities well the investors will have trust on the management and they thus will buy the stock of the bank. Its price increases along the increase of the demand.

\section{CONCLUSION AND IMPLICATION}

\section{Conclusion}

NPL, LDR, CAR, DER, ROA and NPM simultaneously affect stock price of banks listed in Indonesia Stock Exchange in 2014-2018. However, only ROA and NPM that partially affect positively and significantly stock price. However, the independent variables in this research gave only 19,2\% influence on variation of the dependent variable.

The results indicate that banks must pay attention on their ROA and NPM to attract investors because they are the factors considered by the investors. This does not mean that banks can disregard other factors not covered in the research. Coefficient of determination shows that there are other factors than NPL, LDR, CAR, DER, ROA and NPM that are possibly considered by investors or potential investors in assessing banks' financial performance before making the decision. Considering that bank specific factors are unique, banks must thus try to find out the factors relevant to their condition. In relation to this, future research can explore other financial indicators that are not yet covered in this research such as net interest margin, return on risked asset, quick ratio.

\section{REFERENCES}

Ahmad, Moholo, Mahmud. (2018, March). Pengaruh Rasio Keuangan terhadap Harga Saham pada Perusahaan Jasa yang Terdaftar dalam Indeks 1Q45 di Bursa Efek Indonesia (BEI) periode 2012-2016. JAWARA: Jurnal Wawasan dan Riset Akuntansi. 5(2). 
Amanah, Atmanto, Azizah. (2014, July). Pengaruh Rasio Likuiditas dan Rasio Profitabilitas terhadap Harga Saham (Studi pada Perusahaan Indeks LQ45 Periode 2008-2012). Jurnal Administrasi Bisnis (JAB), 12(1).

Ang, Robert. (1997). Buku Pintar Pasar Modal Indonesia. Jakarta: Mediasoft Indonesia.

Bank Indonesia. (1998). Undang-Undang Nomor 10 Tahun 1998 tentang Perubahan UndangUndang No. 7 Tahun 1992 tentang Perbankan. Jakarta: Gramedia.

Dang, U. (2011). The CAMEL Rating System in Banking Supervision: a Case Study of Arcada University of Applied Sciences, International Business.

Fordian, D. (2017, January). Pengaruh CAR, LDR, dan EPS terhadap Harga Saham (Studi Pada Bank BUMN yang Listing di BEI Periode 2012-2016). Jurnal Bisnis Darmajaya, 3(1).

Ghozali, I. (2011). Aplikasi Analisis Multivariate Dengan Program SPSS. Semarang: Badan Penerbit Universitas Diponegoro.

Hery. (2015). Analisis Laporan Keuangan. Yogyakarta: CAPS.

Karamoy, H. Tulung, J.E. (2020). The Effect of Financial performance and Corporate Governance to Stock Price in Non-bank Financial Industry. Corporate Ownership \& Control, 17(2), 97-103, http://doi.org/10.22495/cocv17i2art9

Kartadinata. (2018). Pengaruh NPL, CAR, LDR terhadap Harga Saham, Studi pada Perusahaan Perbankan yang Terdaftar di LQ45 Periode 2012-2016. Thesis. Accessed from http://repository.maranatha.edu/25089/ at 4 October 2019.

Karim, R.A., Alam, T. (2013). An valuation of Financial Performance of Private Commercial Banks in Bangladesh: Ratio Analysis. Journal of Business Studies Quaterly, 5(2), 6577

Kasmir. (2014). Analisis Laporan Keuangan. Jakarta: PT Raja Grafindo Persada.

Kasmir. (2017). Analisis Laporan Keuangan. Jakarta: PT Raja Grafindo Persada.

Malayu, H. (2008). Manajemen Dasar, Pengertian, Dan Masalah. Jakarta: PT Bumi Aksara.

Martanorika. (2018). Pengaruh Loan to Deposit Ratio (LDR), Non-Performing Loan (NPL), Capital Adequacy Ratio (CAR), Net Interest Margin (NIM) terhadap Harga Saham Bank Umum Konvensional yang Terdaftar di Bursa Efek Indonesia pada Tahun 20142016. Thesis. Accessed from https://eprints.uny.ac.id/59989/1/SKRIPSI.pdf at 4 October 2019.

Munawir, S. (2012). Analisis Informasi Keuangan, Yogyakarta: Liberty.

Murerwa, C.B. (2015). Determinant of Banks' Financial Performance in Developing Economies: Evidence from Kenyan Commercial Banks. Thesis. United States International University-Africa, Nairobi. 
Ongore, V.O, Kusa, G.B. (2013). Determinants of Financial Performance of Commercial Banks in Kenya. International Journal of Economics and Financial Issues, 3(1), 237-252

Paska. (2017). Analisis Pengaruh Return on Assets dan Dividend Per Share terhadap Harga Saham. Studi Kasus pada Sepuluh Perusahaan Perbankan di Bursa Efek Indonesia Tahun 2011-2015. Thesis. Accessed from https://repository.usd.ac.id/11637/2/132214065_full.pdf at 4 October 2019.

Sujarweni, W.V. (2015). Statistika Untuk Penelitian. Yogyakarta: Graha Ilmu.

Sugiyono. (2014). Metode Penelitian Manajemen. Bandung: Alfabeta.

Takarini \& Hendrarini. (2018, Mei). Pengaruh Rasio Likuiditas dan Rasio Leverage terhadap Harga Saham (Studi Pada Perusahaan Indeks LQ45 Periode 2014-2016). Jurnal Administrasi Bisnis (JAB), 58(1).

Wijayanto. (2015). Pengaruh Likuiditas, Solvabilitas, Aktivitas, dan Profitabilitas terhadap Harga Saham, Studi Empiris pada Perusahaan Perbankan yang Terdaftar di BEI Tahun 2009-2012. Thesis. Accessed from https://repository.usd.ac.id/668/2/092114057_full.pdf at 4 October 2019.

Yulita \& Rahayu. (2019, March). Hospitality And Tourism Industry Performance in Indonesia Based on Benjamin Graham's Perspective. Jurnal Ilmu Manajemen dan Bisnis, 10(1). 